\title{
Somatic Embryogenesis in Four Tree Legumes
}

\author{
Premananda Das \\ Vision MGM Agri-Tech and Research Institute Pvt. Ltd., C-122 (HIG), Baramunda, Bhubaneswar-751 003, Orissa, India \\ Correspondence should be addressed to Premananda Das, pdas2001@gmail.com
}

Received 20 May 2010; Accepted 16 July 2010

Academic Editor: Masaru Ohme-Takagi

Copyright () 2011 Premananda Das. This is an open access article distributed under the Creative Commons Attribution License, which permits unrestricted use, distribution, and reproduction in any medium, provided the original work is properly cited.

\begin{abstract}
Somatic embryogenesis was achieved in four leguminous tree species, that is, Acacia catechu, Acacia arabica, Hardwickia binata, and Dalbergia sissoo using immature zygotic embryos as explants on Murashige and Skoog (MS) medium supplemented with 0.25-1.0 mg/l Kn (kinetin) and 2.0-3.0 mg/l 2,4-D (2,4-dichlorophenoxyacetic acid) or NAA (1-napthaleneacetic acid) and 3\% sucrose. MS medium containing $2.0 \mathrm{mg} / \mathrm{l} 2,4-\mathrm{D}$ and $1.0-1.5 \mathrm{mg} / \mathrm{l} \mathrm{Kn}$ was noted to be most effective in inducing friable embryogenic callus (FEC); the number of somatic embryos per culture varied in MS medium supplemented with 1.0-2.0 mg/l 2,4-D or NAA and 0.25-1.5 mg/l kinetin. The maximum number of somatic embryos was obtained in MS medium containing 1.5-2.0 mg/l 2,4-D or NAA and 1.0-1.5 mg/l kinetin; proliferation of embryogenic calli was enhanced in cultures having 1.0-2.0 mg/l 2,4-D, 1.0-1.5 mg/l kinetin, and 400-600 mg/l L-Proline. The somatic embryos in various shapes and sizes after the first subculture on MS medium supplemented with $0.1 \mathrm{mg} / \mathrm{l} \mathrm{IAA}$ and $0.25 \mathrm{mg} / \mathrm{l} \mathrm{BA}$; developed shoots and rooted in $1 / 2$ strength MS medium supplemented with $0.1 \mathrm{mg} / \mathrm{l}$ IBA or IAA. The somatic embryo-derived plantlets were transferred to the field after being hardened in the climatecontrolled hardening chamber.
\end{abstract}

\section{Introduction}

Tree legumes, once established, grow faster than other tree species even under poorly managed plantation-forestry systems as they fix atmospheric nitrogen for sustenance and growth. Acacia catechu Willd., a leguminous tree, is used in afforestation and reclamation programmes due to its easy adaptability and rapid growth rate even on marginal soils and wastelands in the tropics [1]. Acacia arabica (Babul), a leguminous tree of tropical and sub-Saharan Africa is naturalized in many parts of peninsular India; as an economically valued timber, it is used for crafting of agricultural implements, building materials, furniture, and fuel wood as well while the leaves and pods are used for fodder; gum arabica has many industrial applications. This species has great ecological value in controlling erosion and improving soil fertility. Hardwickia binata Roxb. is a leguminous tree found in the dry savannah forests of the Deccan peninsula and central India. It grows up to $36.5 \mathrm{~m}$ in height and $4.5 \mathrm{~m}$ in girth with a $12-15 \mathrm{~m}$ clean cylindrical bole. It is one of the most economically important Indian timber trees and is used for construction and ornamental wood work. Its bark is used for tanning, fiber, and paper, its resin is a wood preservative, and its leaves can be used as fodder and manure. Dalbergia sissoo, an important and valuable leguminous tree species, has been used for ages for various purposes. Leguminous plants are difficult to propagate. Propagation through seed is unreliable as mature seeds are often damaged by pod borers followed by bacteria and fungi which cause secondary infections; healthy seeds are rarely available for mass propagation. Poor germination and death of young seedlings are also the causes of worry. Mass cloning via somatic embryogenesis can be an alternative and reliable system for plant multiplication [2]. Somatic embryogenesis was reported for a number of dicotyledonous and monocotyledonous angiosperms but fewer woody species [2-4]. Woody species were recalcitrant to in vitro culture and regeneration and most of those reports focused on propagation or multiplication through organogenesis using various explants. Very meager information on somatic embryogenesis in leguminous tree species was available. It was thought that plants must coordinate the growth of root and shoot meristems to maintain an appropriate balance of root and shoot organs, respond and adapt to various environmental conditions to achieve an intermeristems coordination of growth and development involving the interplay of several long-range signals $[5,6]$. 


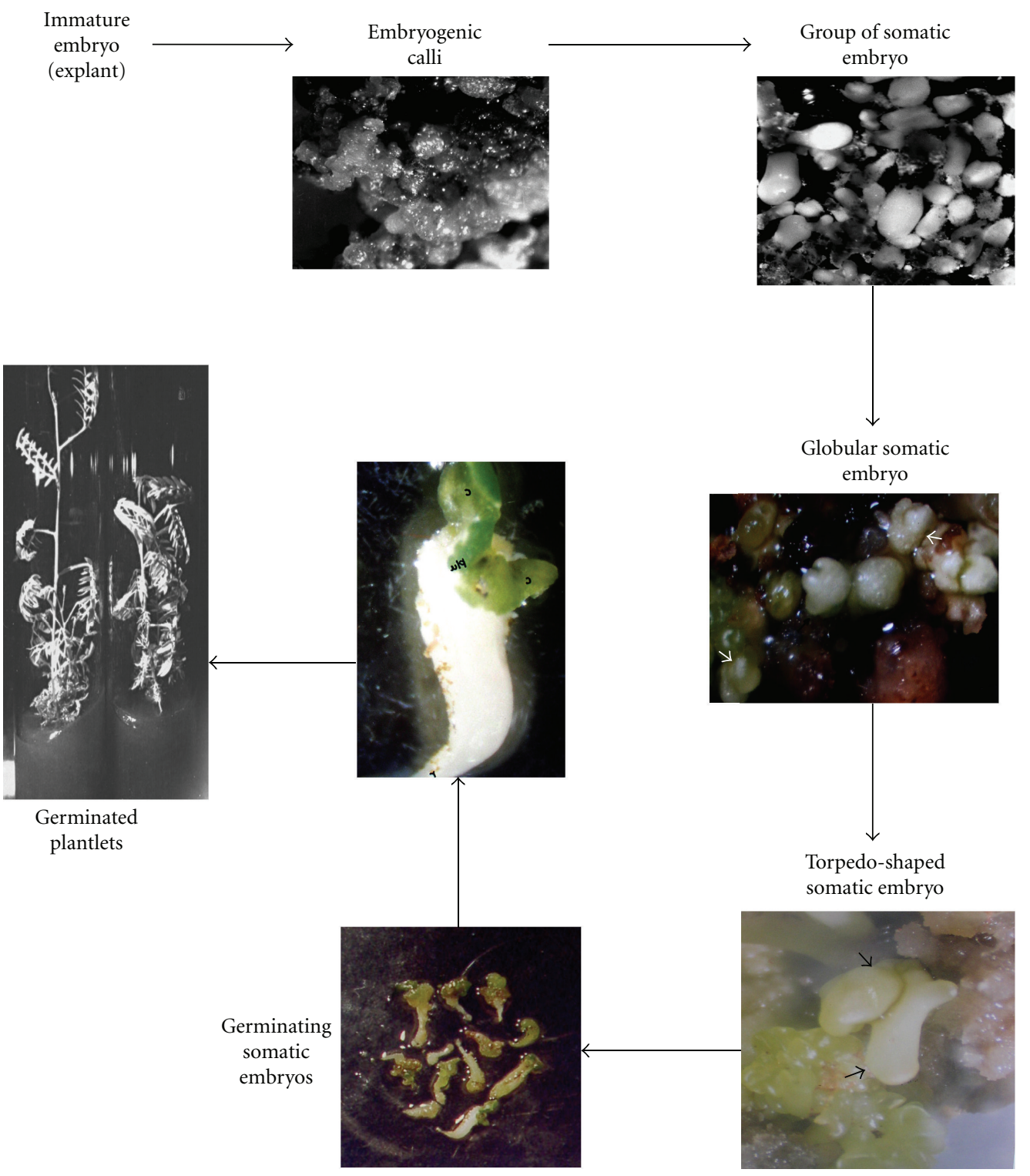

FIgURE 1: Flow chart of in vitro somatic embryogenesis in A.catechu.

The objectives of this study were to investigate the requirements of culture media, including environmental conditions for induction of somatic embryogenesis, maturation, and germination of the embryos in some important leguminous tree species.

\section{Materials and Methods}

2.1. Plant Material. Immature green pods of Acacia arabica, Acacia catechu, Hardwickia binata, and Dalbergia sissoo (60 days after flowering) were collected from elite trees growing in dry deciduous forests. The pods were washed with $2 \%(\mathrm{w} / \mathrm{v})$ detergent solution (Teepol) for $10 \mathrm{~min}$, further ringed with $70 \%$ ethanol for $1 \mathrm{~min}$, surface sterilized with $0.1 \%(\mathrm{w} / \mathrm{v})$ aqueous solution of mercuric chloride for 15 minutes, followed by three 5-minute rinses in sterile distilled water. Embryonic axis along with cotyledons were aseptically cultured on Murashige and Skoog [7] medium supplemented with various concentrations of BA or $\mathrm{Kn}$ $(0,0.25,0.5,1.0,1.5,2.0 \mathrm{mg} / \mathrm{l})$, NAA or $2,4-\mathrm{D}(0,0.5$, $1.0,1.5,2.0,3.0 \mathrm{mg} / \mathrm{l}$ ) alone or in combinations for callus induction. The $\mathrm{pH}$ of the media was adjusted to 5.7 using $0.1 \mathrm{~N} \mathrm{NaOH}$ or $0.1 \mathrm{~N} \mathrm{HCl}$ prior to addition of $0.8 \%(\mathrm{w} / \mathrm{v})$ agar (Qualigen, India). Routinely, $20 \mathrm{ml}$ of molten medium was dispensed into $25 \times 150 \mathrm{~mm}$ glass tubes (Borosil, India), capped with nonabsorbent cotton plugs and wrapped in one layer of cheesecloth. The cultures were sterilized at $121^{\circ} \mathrm{C}$ and $104 \mathrm{kPa}$ for 15 minutes.

2.1.1. Induction of Somatic Embryogenesis. Callus pieces (500 $\pm 20 \mathrm{mg}$ ) were transferred to MS medium supplemented with different concentrations of BA, kinetin, and 2,4-D or NAA $(0,0.25,0.5,1.0,1.5,2.0,2.5$ and $3.0 \mathrm{mg} / \mathrm{l})$ singly 


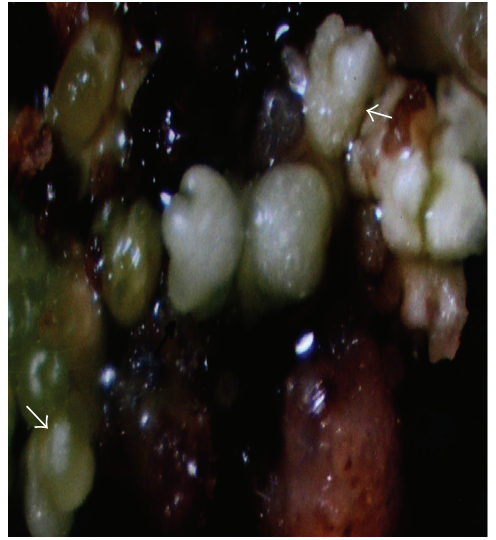

(a)

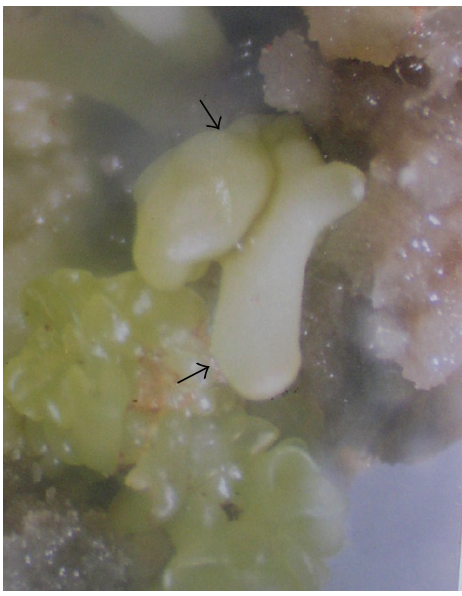

(d)

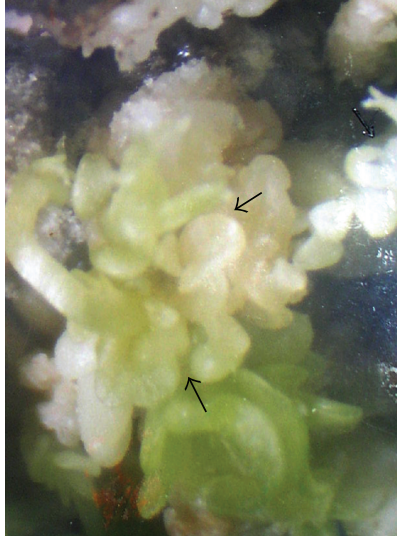

(b)

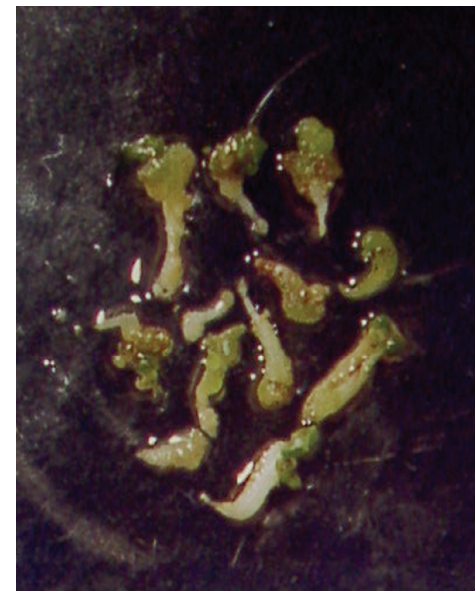

(e)

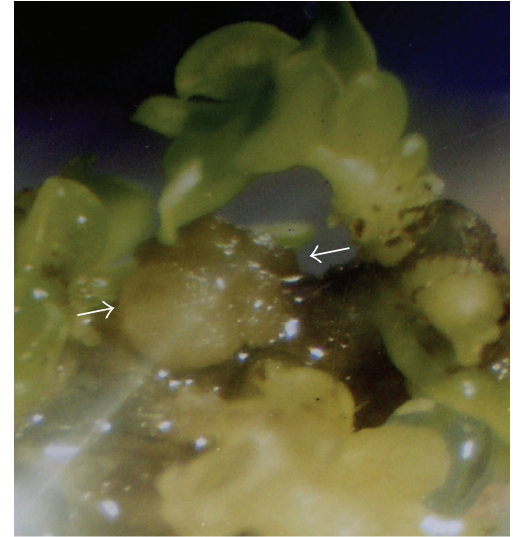

(c)

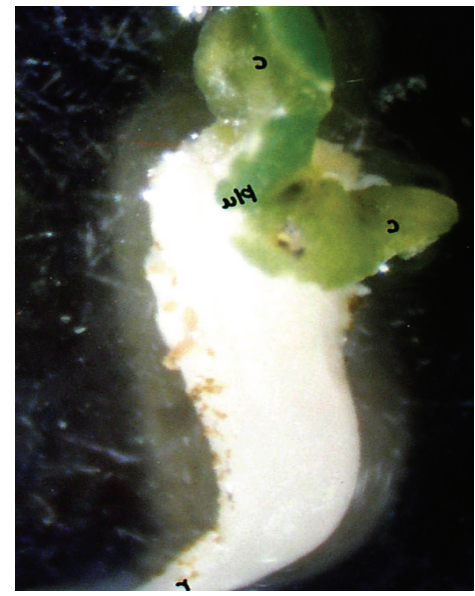

(f)

FIGURE 2: In Vitro somatic embryogenesis of Acacia catechu. (a) Development of embryogenic callus from immature zygotic embryos on MS medium $+1.5 \mathrm{mg} / \mathrm{l} \mathrm{Kn}, 2.0 \mathrm{mg} / \mathrm{l}$ 2,4-D after 4 weeks of culture. (b, c) Secondary somatic embryogenesis on medium having $1.5 \mathrm{mg} / \mathrm{l}$ $\mathrm{Kn}, 2.0 \mathrm{mg} / \mathrm{l}$ 2,4-D after 4 weeks of subculture. (d) Globular and torpedo-shaped somatic embryos. (e) Germination of somatic embryos on $1 / 2$ strength MS medium supplemented with $0.1 \mathrm{mg} / \mathrm{l} \mathrm{IAA}, 0.25 \mathrm{mg} / \mathrm{l} \mathrm{BA}$ and $2 \%$ sucrose after 2 weeks of culture. (f) Somatic embryo germinated into plantlet with cotyledons and plumule.

or in combinations for induction of somatic embryogenesis. The cultures were incubated under $16 \mathrm{~h}$ photoperiod with light intensity of $55 \mu \mathrm{molm}^{-2} \mathrm{~s}^{-1}$ provided by cool, white fluorescent lamps (Phillips, India) at $25 \pm$ $2{ }^{\circ} \mathrm{C}$. Morphological changes were recorded through visual observations at 3-week intervals. L-proline was added to the culture medium to enhance the embryogenic potential. The media were solidified with $0.8 \%$ agar-agar. Subculturing was made every 4 -week intervals. The embryogenic response and number of somatic embryos per culture were recorded.

\section{Germination of Somatic Embryos}

The embryogenic callus was transferred to various culture media with or without growth regulators for maturation and germination. The medium was supplemented with $0.1-0.25 \mathrm{mg} / \mathrm{l}$ IAA or IBA and $2 \%$ sucrose for maturation and germination of somatic embryos, 5-10 mg/l ascorbic acid was added alone or in combinations for better response. The cultures were regularly subcultured at 4-week intervals. After 4 weeks of culture, germination of normal embryos was recorded. In another experiment, the cultures were kept in the dark for 2 weeks, which were then transferred to the light for germination of somatic embryos. In all the experiments, each treatment consisted of three replications, and the experiments were repeated twice. In some cases, somatic embryos lacked proper root system; the shoots were transferred to $1 / 2 \mathrm{MS}$ medium supplemented with $2 \%$ sucrose and IBA $(0.1-0.25 \mathrm{mg} / \mathrm{l})$ for root induction.

The flow chart of the pathway of induction and germination of somatic embryos is indicated in Figure 1.

\section{Results and Discussion}

Friable calli developed from immature zygotic embryos within 3-4 weeks of culture on MS medium supplemented with various concentrations of auxins and cytokinins. The 


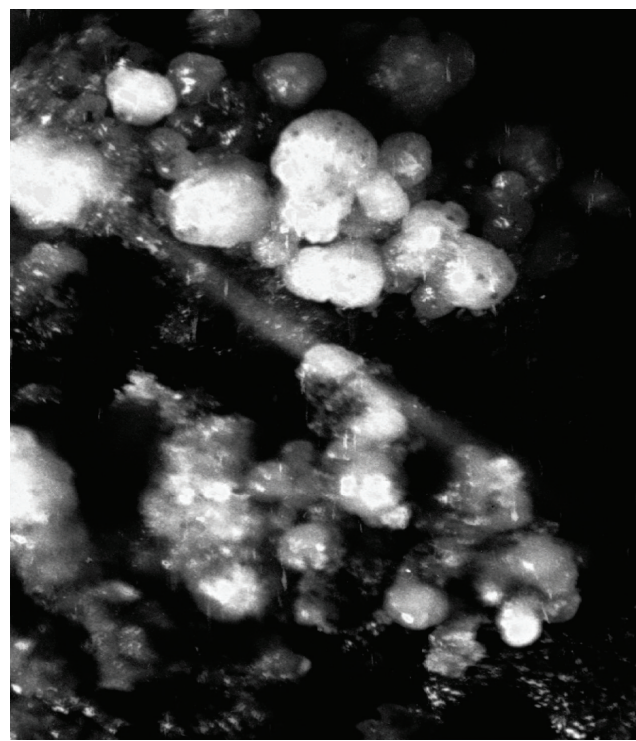

(a)

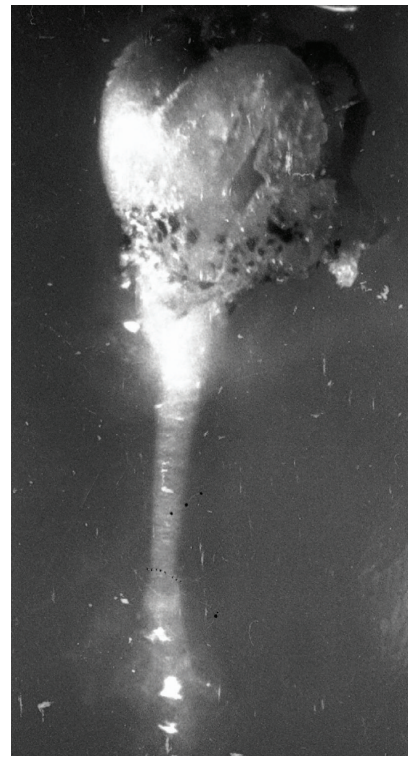

(c)

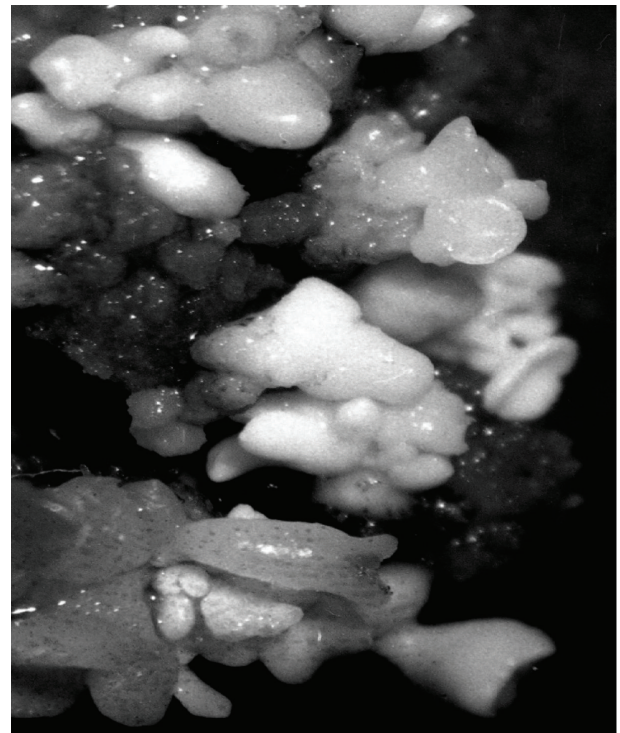

(b)

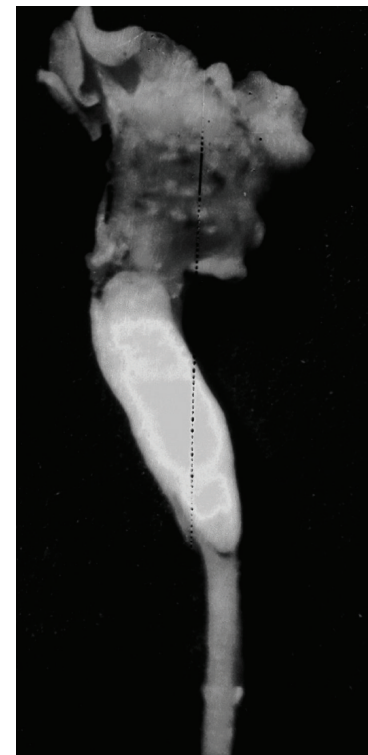

(d)

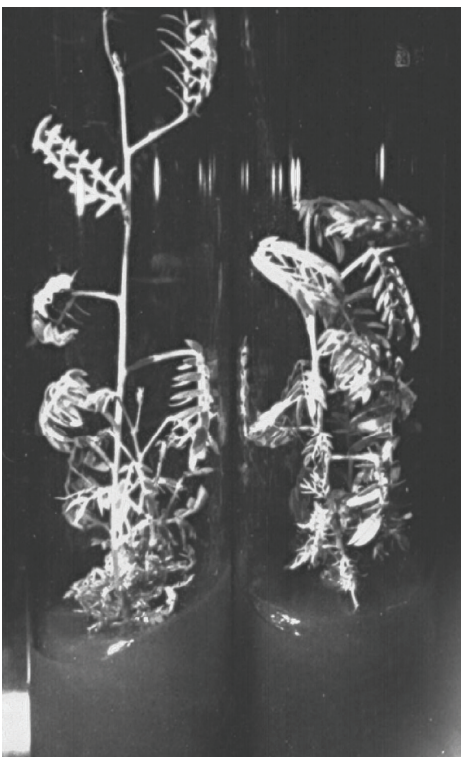

(e)

FIGURE 3: In Vitro somatic embryogenesis in Acacia Arabica. (a) Development of embryogenic callus from immature zygotic embryos on MS medium $+1.5 \mathrm{mg} / \mathrm{l} \mathrm{Kn}, 2.0 \mathrm{mg} / \mathrm{l}$ 2,4-D after 4 weeks of culture. (b) Secondary somatic embryogenesis on medium having $1.5 \mathrm{mg} / \mathrm{l} \mathrm{Kn}, 2.0$ mg/l 2,4-D after 4 weeks of subculture. (c, d) Torpedo shaped somatic embryos. (e) Somatic embryo derived plantlets on 1/2 strength MS medium supplemented with $0.25 \mathrm{mg} / \mathrm{l} \mathrm{BA}$ and $2 \%$ sucrose after 3 weeks of culture.

maximum proliferation of callus was noted in the medium containing kinetin, and 2,4-D. Kinetin was more responsive to callus induction as compared to BA. BA with NAA in the medium was also not very responsive to callus proliferation. The proliferated calli were subsequently subcultured on various media for induction of embryogenesis. Embryogenic calli developed on MS medium supplemented with 0.25-1.5 mg/l kinetin and 2.0-3.0 mg/l 2,4-D. The medium devoid of growth regulators did not promote proliferation of embryogenic calli. The maximum rate of callus proliferation was noted on MS medium supplemented with
0.25-1.5 mg/l kinetin and $2.0 \mathrm{mg} / \mathrm{l} 2,4-\mathrm{D}$ in Dalbergia sissoo and $1.5-2.0 \mathrm{mg} / \mathrm{l}$ kinetin and $1.5-2.0 \mathrm{mg} / \mathrm{l} 2,4-\mathrm{D}$ or NAA in Acacia arabica, Acacia catechu (Figure 2(a)), and Hardwickia binata (Table 1). Proliferation of friable embryogenic calli was better in the medium having kinetin as compared to BA in terms of fresh weight. Similar responses were observed when NAA was replaced with 2,4-D. Kinetin at a concentration of $1.0 \mathrm{mg} / \mathrm{l}$ along with $2.0 \mathrm{mg} / \mathrm{l} 2,4-\mathrm{D}$ improved the rate of embryogenic callus proliferation and in the production of large number of somatic embryos per culture; 2,4-D though helped in the proliferation of 


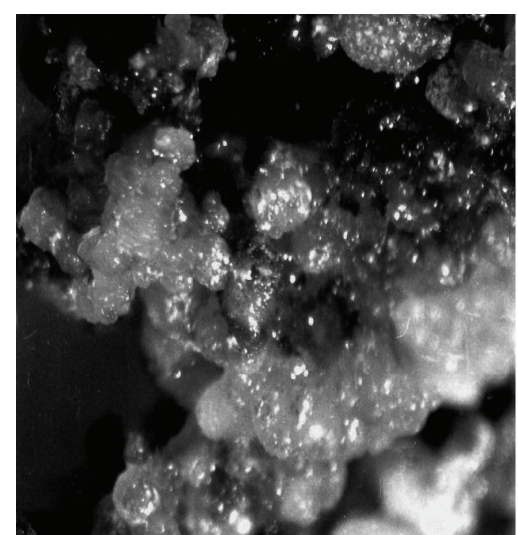

(a)

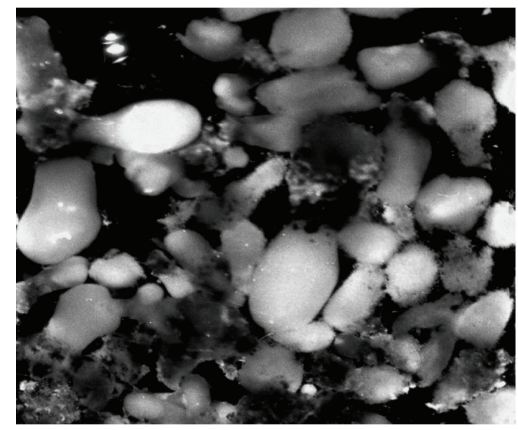

(c)

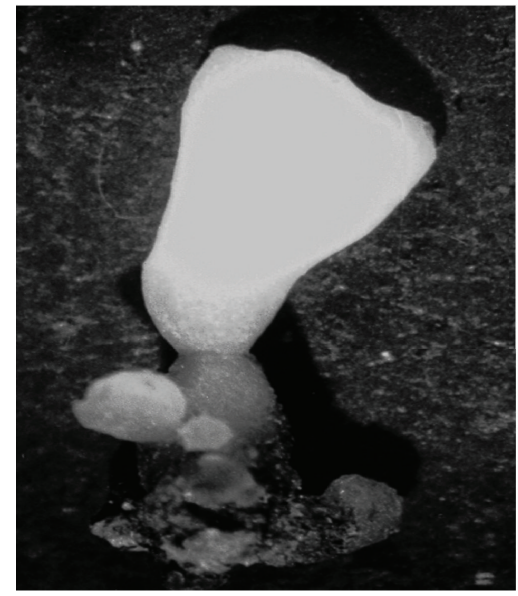

(e)

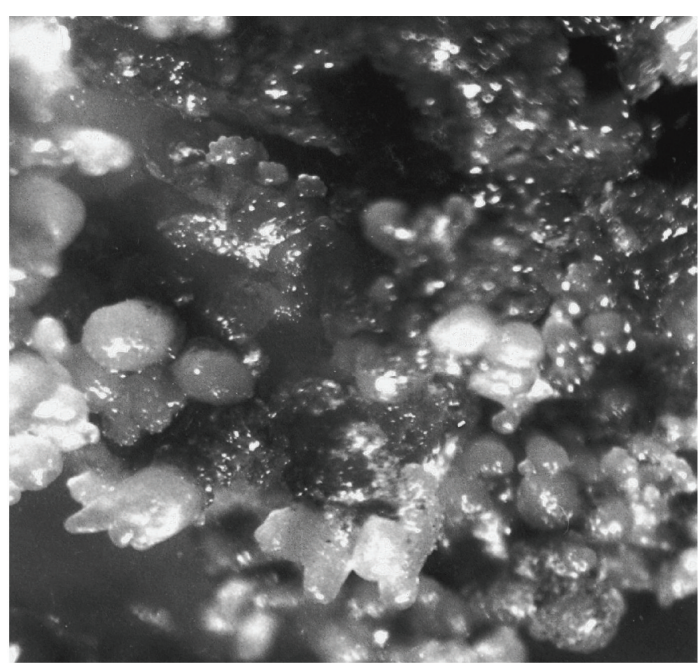

(b)

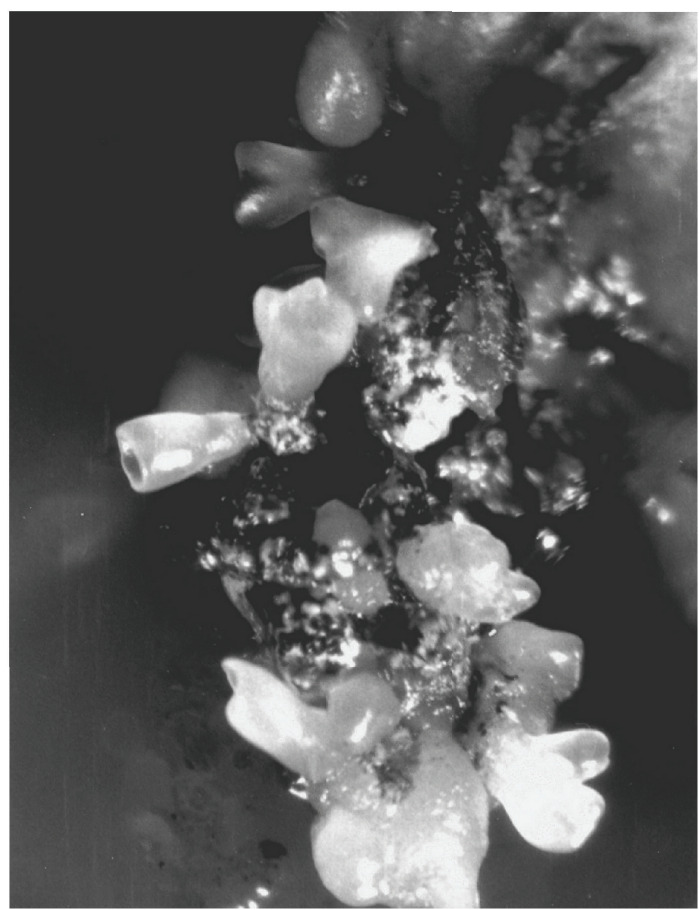

(d)

Figure 4: In Vitro somatic embryogenesis in Hardwickia binata. (a) Development of embryogenic callus from immature zygotic embryos on MS medium $+1.0 \mathrm{mg} / \mathrm{l} \mathrm{Kn}, 2.0 \mathrm{mg} / \mathrm{l}$ 2,4-D after 4 weeks of culture. (b, c) Secondary somatic embryogenesis on medium having $1.0 \mathrm{mg} / \mathrm{l}$ $\mathrm{Kn}, 2.0 \mathrm{mg} / \mathrm{l}$ 2,4-D after 4 weeks of subculture. (d) Globular and torpedo shaped somatic embryos germinating on 1/2 strength MS medium supplemented with $0.1 \mathrm{mg} / \mathrm{l} \mathrm{IAA}, 0.25 \mathrm{mg} / \mathrm{l} \mathrm{BA}$ and $2 \%$ sucrose after 2 weeks of culture.

embryogenic callus as good as the NAA, few somatic embryos developed (Table 2). However, embryogenic callus induction was faster in the medium containing 2,4-D as compared to the media having NAA. Embryo development from somatic cells was often accompanied with cellular stress. Moreover, 2,4-D, the most frequently used compound for induction of somatic embryogenesis, is known to activate many stress-related genes supporting the hypothesis that somatic embryogenesis results due to extreme stress response of cultured cells. Proline acts as a potential antioxidant, which helps in ameliorating the stress. Globular embryos developed into heart and torpedo shaped embryos faster in media containing 2,4-D and kinetin (Figures 2(b) and 2(c)). In woody species, explants from immature seeds or young seedlings generally exhibited greater ability for somatic embryogenesis than mature tissues [8]. The developmental pathway of induction of somatic embryogenesis in 


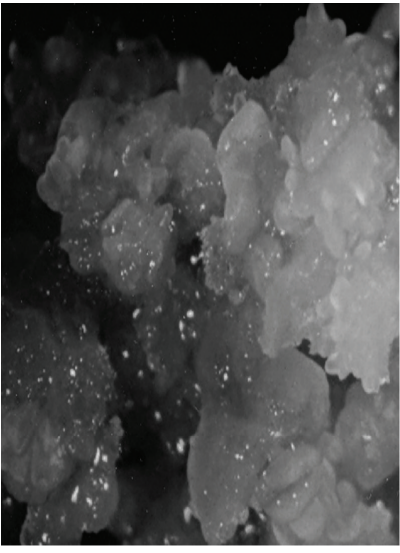

(a)

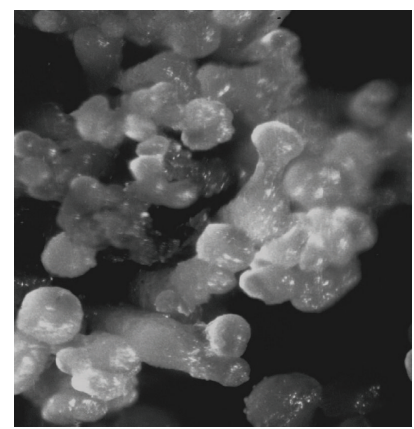

(d)

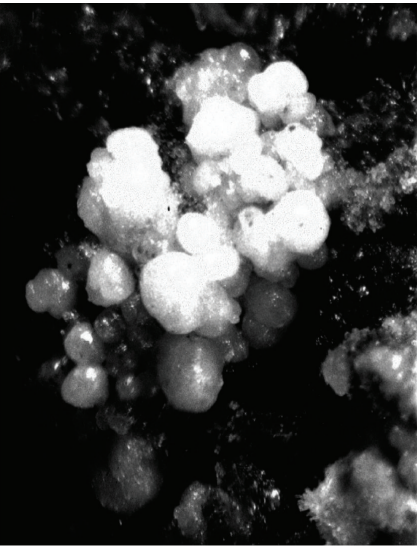

(b)

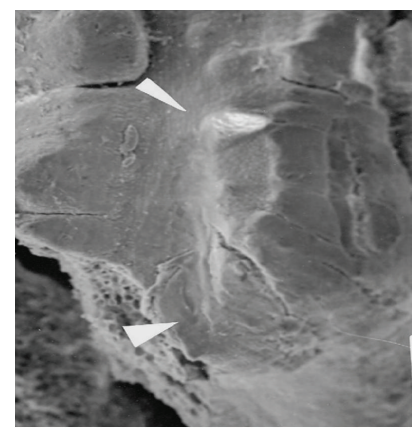

(e)

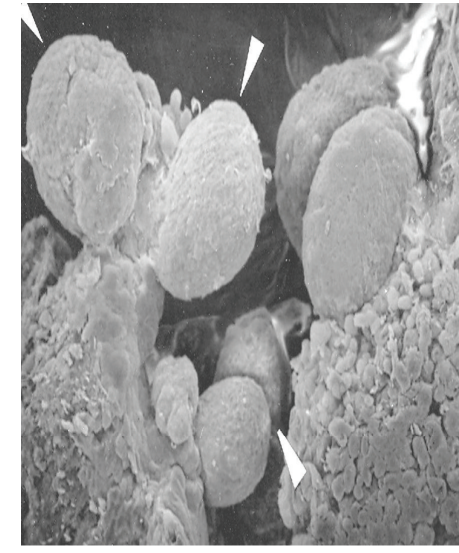

(c)

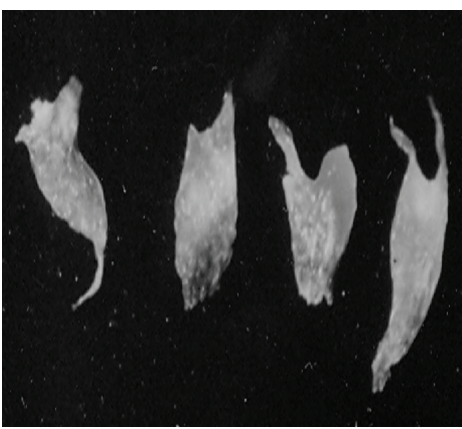

(f)

Figure 5: In Vitro somatic embryogenesis in Dalbergia sissoo. (a) Development of embryogenic callus from immature zygotic embryos on MS medium $+1.0 \mathrm{mg} / \mathrm{Kn}, 2.0 \mathrm{mg} / \mathrm{l}$ 2,4-D after 4 weeks of culture. (b) Primary and secondary somatic embryogenesis on medium having $1.0 \mathrm{mg} / \mathrm{Kn}, 2.0 \mathrm{mg} / \mathrm{l}$ 2,4-D after 4 weeks of subculture. (c) Scanning Electron Microscopy (SEM) of globular embryos. (d) Globular somatic embryos. (e) SEM of germination of somatic embryos on 1/2 strength MS medium supplemented with 0.1 mg/l IAA, 0. $25 \mathrm{mg} / \mathrm{l} \mathrm{BA}$ and 2\% sucrose after 2 weeks of culture. (f) Somatic embryos with cotyledons and radicle.

TABLE 1: Effect of cytokinins and auxins on induction of embryogenic callus from immature zygotic embryos of Dalbergia sissoo (DS), Acacia catechu (AC), Acacia arabica (AA), and Hardwickia binata (HB).

\begin{tabular}{|c|c|c|c|c|c|c|c|}
\hline \multicolumn{4}{|c|}{ MS + growth regulator $(\mathrm{mg} / \mathrm{l})$} & \multicolumn{4}{|c|}{ Percent of explant response (Mean \pm SE)* } \\
\hline BA & $\mathrm{Kn}$ & NAA & $2,4-\mathrm{D}$ & DS & $\mathrm{AC}$ & AA & $\mathrm{HB}$ \\
\hline 0 & 0.25 & 0.5 & 0 & $20.4 \pm 0.6(\mathrm{NE})$ & $18.6 \pm 0.7(\mathrm{NE})$ & $31.2 \pm 0.6(\mathrm{NE})$ & $29.4 \pm 0.6(\mathrm{NE})$ \\
\hline 0 & 0.25 & 1.0 & 0 & $24.2 \pm 0.8(\mathrm{NE})$ & $28.8 \pm 0.6(\mathrm{NE})$ & $36.4 \pm 0.7(\mathrm{NE})$ & $32.2 \pm 0.8(\mathrm{NE})$ \\
\hline 0 & 0.25 & 2.0 & 0 & $54.8 \pm 0.7(\mathrm{NE})$ & $42.4 \pm 0.7(\mathrm{E})$ & $42.8 \pm 0.6(\mathrm{E})$ & $45.6 \pm 0.7(\mathrm{NE})$ \\
\hline 0 & 0.5 & 2.0 & 0 & $62.4 \pm 0.8(\mathrm{NE})$ & $50.6 \pm 0.8(\mathrm{E})$ & $46.6 \pm 0.8(\mathrm{E})$ & $50.2 \pm 0.8(\mathrm{NE})$ \\
\hline 0 & 0.5 & 3.0 & 0 & $72.8 \pm 0.6(\mathrm{NE})$ & $62.5 \pm 0.6(\mathrm{E})$ & $58.8 \pm 0.7(\mathrm{E})$ & $60.2 \pm 0.6(\mathrm{NE})$ \\
\hline 0.25 & 0 & 1.0 & 0 & $26.2 \pm 0.7(\mathrm{NE})$ & $30.4 \pm 0.9(\mathrm{NE})$ & $28.7 \pm 0.9(\mathrm{NE})$ & $34.4 \pm 0.9(\mathrm{NE})$ \\
\hline 0.50 & 0 & 2.0 & 0 & $34.6 \pm 0.8(\mathrm{NE})$ & $44.3 \pm 0.6(\mathrm{NE})$ & $46.2 \pm 0.7(\mathrm{NE})$ & $52.1 \pm 1.0(\mathrm{NE})$ \\
\hline 1.00 & 0 & 3.0 & 0 & $54.2 \pm 0.7(\mathrm{NE})$ & $61.6 \pm 0.8(\mathrm{NE})$ & $56.4 \pm 0.6(\mathrm{NE})$ & $56.6 \pm 0.4(\mathrm{NE})$ \\
\hline 0 & 0.25 & 0 & 1.0 & $32.8 \pm 0.9(\mathrm{E})$ & $42.2 \pm 0.7(\mathrm{E})$ & $46.9 \pm 0.2(\mathrm{E})$ & $52.6 \pm 0.8(\mathrm{E})$ \\
\hline 0 & 0.25 & 0 & 2.0 & $45.8 \pm 0.6(\mathrm{E})$ & $56.7 \pm 0.8(\mathrm{E})$ & $62.2 \pm 0.5(\mathrm{E})$ & $66.2 \pm 0.9(\mathrm{E})$ \\
\hline 0 & 0.5 & 0 & 3.0 & $68.8 \pm 0.8(\mathrm{E})$ & $60.4 \pm 1.0(\mathrm{E})$ & $72.5 \pm 0.7(\mathrm{E})$ & $78.4 \pm 0.8(\mathrm{E})$ \\
\hline 0 & 1.0 & 0 & 2.0 & $75.2 \pm 0.6(\mathrm{E})$ & $58.8 \pm 0.7(\mathrm{E})$ & $64.4 \pm 0.8(\mathrm{E})$ & $66.2 \pm 0.7(\mathrm{E})$ \\
\hline 0 & 1.5 & 0 & 2.0 & $76.2 \pm 0.8(\mathrm{E})$ & $66.2 \pm 1.1(\mathrm{E})$ & $72.3 \pm 0.7(\mathrm{E})$ & $76.6 \pm 1.0(\mathrm{E})$ \\
\hline 0.25 & 0 & 0 & 2.0 & $56.6 \pm 0.7(\mathrm{NE})$ & $45.6 \pm 0.8(\mathrm{NE})$ & $52.5 \pm 0.6(\mathrm{NE})$ & $56.9 \pm 1.1(\mathrm{NE})$ \\
\hline 0.50 & 0 & 0 & 3.0 & $64.4 \pm 0.6(\mathrm{NE})$ & $54.2 \pm 1.0(\mathrm{NE})$ & $58.2 \pm 0.5(\mathrm{NE})$ & $68.4 \pm 0.5(\mathrm{NE}) \mathrm{e}$ \\
\hline
\end{tabular}

*20 Replicates per culture; repeated thrice. NE-Non-embryogenic Calli, E-Embryogenic Calli. 
TABle 2: Development of different sizes of somatic embryos from embryogenic callus of Dalbergia sissoo (DS), Acacia catechu (AC), Acacia arabica (AA), and Hardwickia binata (HB) cultured on different induction medium after 4 weeks of subculture.

\begin{tabular}{|c|c|c|c|c|}
\hline \multirow[t]{2}{*}{ Culture medium $+3 \%(\mathrm{w} / \mathrm{v})$ sucrose } & \multicolumn{4}{|c|}{ No of somatic embryos per $500 \mathrm{mg}$ embryogenic calli $(\text { Mean } \pm \mathrm{SE})^{*}$} \\
\hline & DS & $\mathrm{AC}$ & AA & $\mathrm{HB}$ \\
\hline $\mathrm{MS}+0.25 \mathrm{mg} / \mathrm{l} \mathrm{Kn}+1.0 \mathrm{mg} / \mathrm{l} \mathrm{NAA}$ & $52.4 \pm 0.7$ & 0 & 0 & 0 \\
\hline $\mathrm{MS}+0.5 \mathrm{mg} / \mathrm{l} \mathrm{Kn}+1.5 \mathrm{mg} / \mathrm{l} 2,4-\mathrm{D}$ & $24.8 \pm 0.6$ & $108.2 \pm 1.3$ & $125.2 \pm 0.8$ & $85.6 \pm 0.5$ \\
\hline $\mathrm{MS}+1.0 \mathrm{mg} / \mathrm{l} \mathrm{Kn}+2.0 \mathrm{mg} / \mathrm{l} 2,4-\mathrm{D}$ & $20.6 \pm 0.7$ & $126.4 \pm 1.2$ & $132.6 \pm 0.6$ & $122.2 \pm 0.8$ \\
\hline $\mathrm{MS}+1.5 \mathrm{mg} / \mathrm{l} \mathrm{Kn}+2.0 \mathrm{mg} / \mathrm{l} 2,4-\mathrm{D}$ & $25.7 \pm 0.9$ & $134.2 \pm 0.8$ & $134.6 \pm 0.8$ & $111.6 \pm 0.6$ \\
\hline $\mathrm{MS}+1.5 \mathrm{mg} / \mathrm{l} \mathrm{Kn}+2.0 \mathrm{mg} / \mathrm{l}$ 2,4-D + $400 \mathrm{mg} / \mathrm{l} \mathrm{L-proline}$ & $42.4 \pm 1.1$ & $152.6 \pm 0.7$ & $168.4 \pm 1.2$ & $121.7 \pm 1.2$ \\
\hline $\mathrm{MS}+1.5 \mathrm{mg} / \mathrm{l} \mathrm{Kn}+2.0 \mathrm{mg} / \mathrm{l}$ 2,4-D + $600 \mathrm{mg} / \mathrm{l} \mathrm{L-proline}$ & $46.3 \pm 0.6$ & $160.1 \pm 1.5$ & $172.6 \pm 1.3$ & $128.4 \pm 1.1$ \\
\hline
\end{tabular}

(10 replicates per treatment; repeated thrice)

* Data collected after four weeks of culture on proliferation medium.

Acacia Arabica, Hardwickia binata, and Dalbergia sissoo are indicated in Figures 3, 4, and 5.

The somatic embryos under different treatments were counted. The medium having $1.0 \mathrm{mg} / \mathrm{l} \mathrm{NAA}$ and $0.25 \mathrm{mg} / \mathrm{l}$ Kn produced the maximum number of somatic embryos (52.4 per culture) in Dalbergia sissoo. Although $2.0-3.0 \mathrm{mg} / \mathrm{l}$ 2,4-D in combination with $1.0 \mathrm{mg} / \mathrm{l}$ kinetin helped in the induction of large number of somatic embryos, browning of the embryos was observed; MS medium containing 2,4D was better for maintenance of embryogenic cultures. In other species, more number of somatic embryos were produced in the medium supplemented with $2.0 \mathrm{mg} / \mathrm{l} 2,4-$ $\mathrm{D}$ and $1.0 \mathrm{mg} / \mathrm{l} \mathrm{Kn}$ and the maximum proliferation of somatic embryos per $500 \mathrm{mg}$ of callus were noted in Table 2 . Inclusion of L-proline in the induction medium enhanced proliferation of embryogenic calli. Stimulation of auxin induced somatic embryogenesis in presence of proline has been well documented [9]. Free proline might act as an osmoticum, a nitrogen storage pool and source of $\mathrm{NADP}^{+}$, necessary for rapidly growing embryos. The mediation of the cellular redox potential that results from proline accumulation is likely to have a significant effect on the flux through redox-sensitive biochemical pathways like pentose phosphate pathway [10].

\section{Germination of Somatic Embryos}

Both globular and cotyledonary somatic embryos developed on MS medium supplemented with $0.1 \mathrm{mg} / \mathrm{l} \mathrm{IAA}$ in combination with $0.1 \mathrm{mg} / \mathrm{l} \mathrm{BA}$ (Figure 2(d)). Subsequently, the cotyledonary embryos were maintained in $1 / 2$ strength MS medium along with $0.1 \mathrm{mg} / \mathrm{l} \mathrm{IAA}, 0.1 \mathrm{mg} / \mathrm{l} \mathrm{BA}$ to promote the development of plumule and radicle simultaneously (Figures 2(e) and 2(f)). In some cases, high percentage of cotyledonary embryos were recovered when $10 \mathrm{mg} / \mathrm{l}$ ascorbic acid was added to the medium. Ascorbic acid was an important metabolite involved in many cellular processes, including cell division, and large amount of ascorbate was utilized during initial stages of germination by both zygotic and somatic embryos. Ascorbate also acted as antioxidant and prevented tissue browning by alleviating oxidative stress. In white spruce, ascorbate in germination media increased the conversion frequency of somatic embryos [11].
Although there were high rate of embryo development, abnormalities in the somatic embryos were also frequently observed which consisted of globular embryos, secondary somatic embryos, and callus formation at the root pole. Generally, the somatic embryos produced shoot and root simultaneously. However, in some plant species, somatic embryos produced only shoots without roots [12]. Root initiation in embryo-derived shoots were achieved in IBAcontaining medium. The rooted plantlets were established in the climate-controlled greenhouse.

\section{References}

[1] "Anonymous," in The Wealth of India: A Dictionary of Indian Raw Material and industrial Products, vol. 1: A, pp. 37-47, CSIR, New Delhi, India, 1985.

[2] P. V. Ammirato, "The regulation of somatic embryo development in plant cell cultures: suspension culture techniques and hormone requirements," Nature Biotechnology, vol. 1, pp. 6874, 1983.

[3] G. Maheswaran and E. G. Williams, "Direct secondary somatic embryogenesis from immature sexual embryos of Trifolium repens cultured in vitro," Annals of Botany, vol. 57, no. 2, pp. 109-117, 1986.

[4] L. Bonneau, N. Beranger-Novat, and J. Monin, "Somatic embryogenesis and plant regeneration in a woody species: the European spindle tree (Euonymus europaeus L.)," Plant Cell Reports, vol. 13, no. 3-4, pp. 135-138, 1994.

[5] Q. Jiang and P. M. Gresshoff, "Shoot control of hypernodulation and aberrant root formation in the har1-1 mutant of Lotus japonicus," Functional Plant Biology, vol. 29, no. 11, pp. 1371-1376, 2002.

[6] I. R. Searle, A. E. Men, T. S. Laniya et al., "Long-distance signaling in nodulation directed by a CLAVATA1-like receptor kinase," Science, vol. 299, no. 5603, pp. 109-112, 2003.

[7] T. Murashige and F. Skoog, "A revised medium for rapid growth and bioassay with tobacco tissue cultures," Plant Physiology, vol. 15, pp. 473-497, 1962.

[8] R. L. Mott, “Tree," in Cloning Agricultural Plants via In Vitro Techniques, B. V. Conger, Ed., pp. 217-256, CRC Press, Boca Raton, Fla, USA, 1981.

[9] K. Shetty and B. D. McKersie, "Proline, thioproline and potassium mediated stimulation of somatic embryogenesis in alfalfa (Medicago sativa L.)," Plant Science, vol. 88, no. 2, pp. 185-193, 1993.

[10] S. K. Ghanti, K. G. Sujata, S. Rao, M. Udayakumar, and P. 
B. Kavi Kishor, "Role of enzymes and identification of stagespecific proteins in developing somatic embryos of chickpea (Cicer arietinum L.)," In Vitro Cellular and Developmental Biology, vol. 45, no. 6, pp. 667-672, 2009.

[11] C. Stasolla, M. S. W. Lam, and E. C. Yeung, "Exogenous applications of ascorbic acid enhance shoot apical meristem growth and induce shoot organogenesis in germinating white spruce (Picea glauca) somatic embryos," International Journal of Plant Sciences, vol. 167, no. 3, pp. 429-436, 2006.

[12] S. Te-chato, C. Nualsri, and K. Kanchanapoom, "Somatic embryogenesis of oil palm (Elaeis guineensis Jacq.) subsequent to plantlet regeneration," Microbial Utilization of Renewable Resources, vol. 6, pp. 99-104, 1988. 

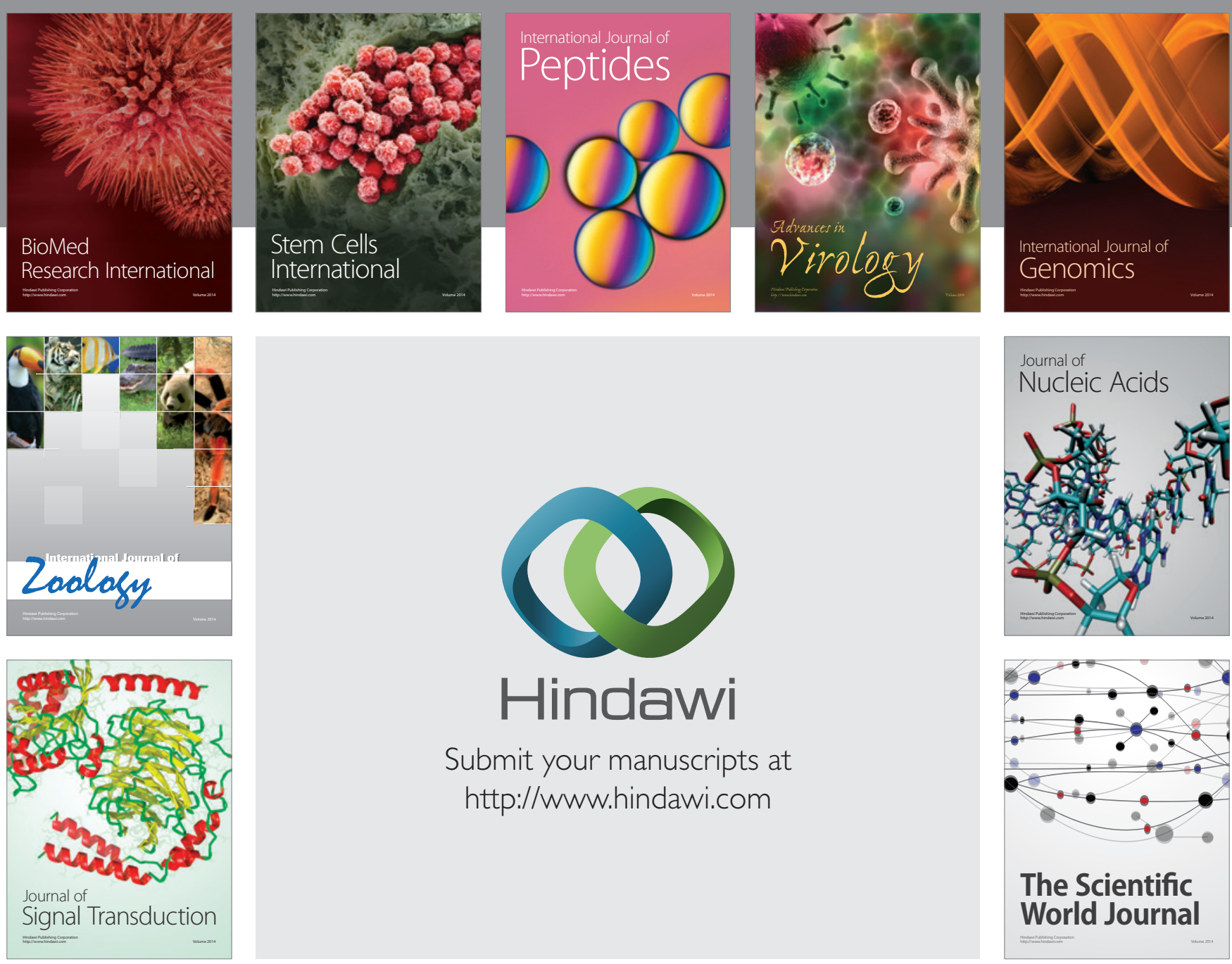

Submit your manuscripts at

http://www.hindawi.com
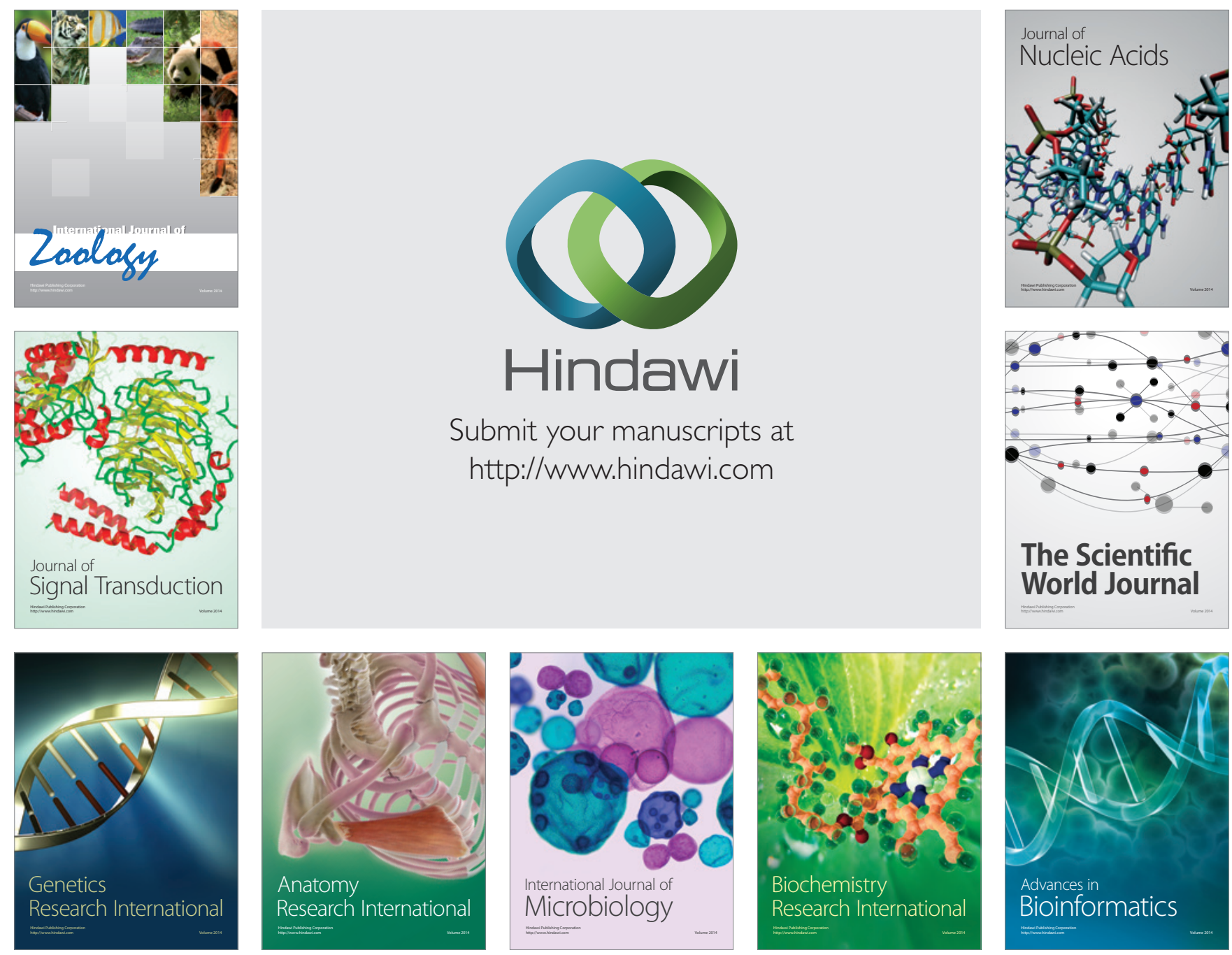

The Scientific World Journal
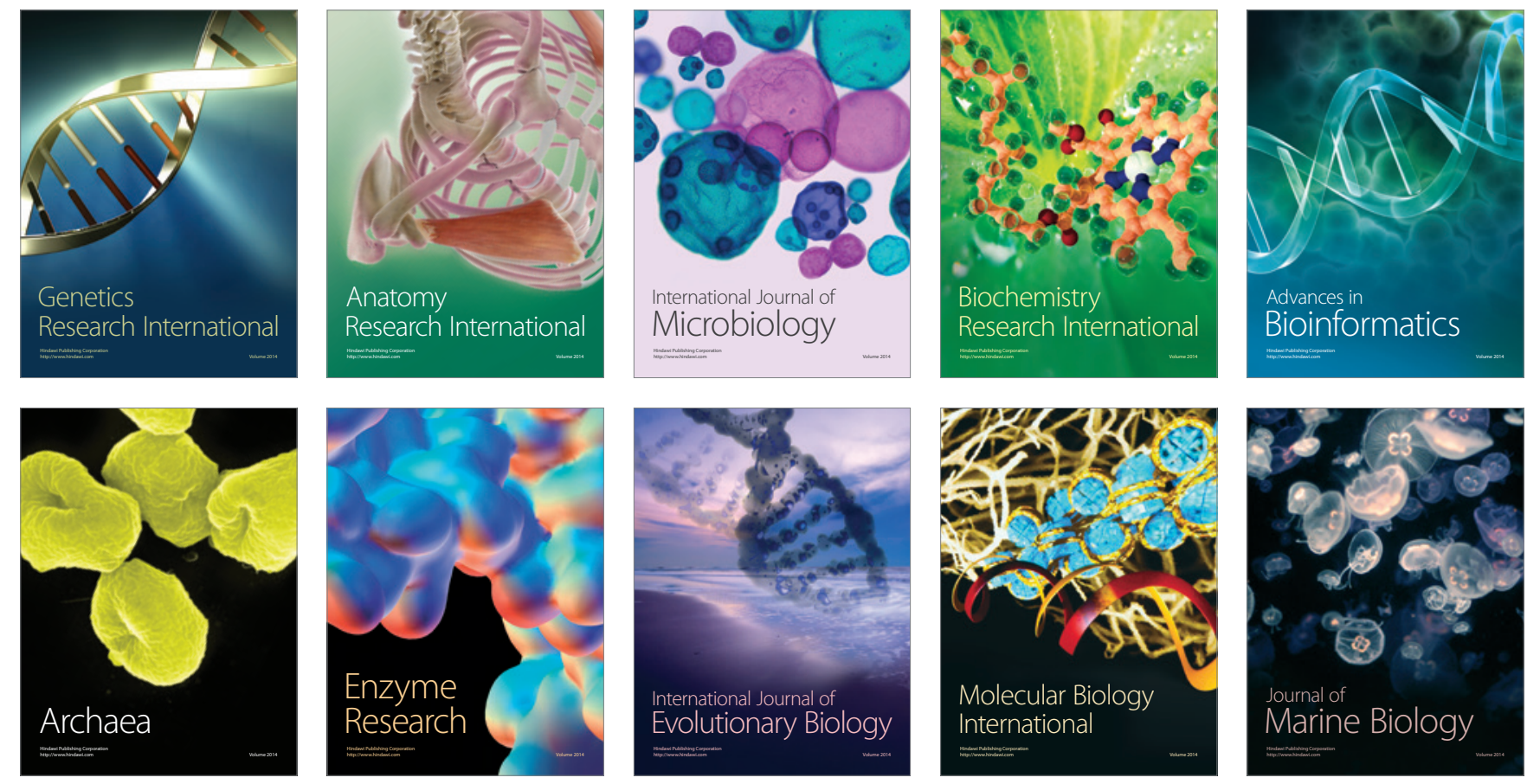